\title{
EFFECTS OF IBA AND PLANT GROWTH-PROMOTING RHIZOBACTERIA (PGPR) ON ROOTING OF RAMSEY AMERICAN GRAPEVINE ROOTSTOCK
}

\author{
İşÇI, B. * KACAR, E. - ALTINDİşLI, A. \\ Ege University, Faculty of Agriculture, Department of Horticulture \\ Bornova/Izmir, Turkey \\ *Corresponding author \\ e-mail: burcak.isci@ege.edu.tr; ID: 0000-0002-6542-0271
}

(Received 30 $0^{\text {th }}$ Dec 2018; accepted $27^{\text {th }}$ Feb 2019)

\begin{abstract}
This experiment was conducted to reveal the effects of PGPR and IBA on rooting characteristics of Ramsey "Salt Creek" (Vitis champini) under the nursery. Hard wood cuttings of Ramsey were subjected to PGPR (EMA1, EMA6, EMA24, EMA MEDIA, EMA CALLUS, EMA QUICK DIP) with dipping times of $1 \mathrm{~h}, 6 \mathrm{~h}, 24 \mathrm{~h}$. IBA concentration was $25,2000,4000 \mathrm{ppm}$ with dipping time of $24 \mathrm{~h}$ in the case of long-soak method, and of 4 seconds in quick dip method. Data were recorded on specific rooting and shooting characteristic. Results obtained from treatments showed significant differences at $\mathrm{p} \leq 0.01$ for specific rooting characteristic, like rooting rate $(\%)$, rooting degree $(0-4)$, root length $(\mathrm{cm})$, root fresh and dry weight $(\mathrm{g})$ under the interaction between PGPR and IBA concentration and dipping time. The rooting rate of EMA1 was $56.7 \%$, and was better than in IBA treatments. Rooting degree (0-4) was 3.5 with EMA1 and 3.3 with EMA MEDIA. The highest root lenght (cm) were obtained in IBA25 (37.6) EMA MEDIA (37.2) and EMA1 (34.1). The best result on fresh root weight (g) was determined with EMA1 (9.8) and EMA6 (9.5). As a conclusion, inspected rooting characteristics generally increased with the EMA1 and EMA6 treatments.
\end{abstract}

Keywords: Vitis vinifera, nursery, cutting, dipping, rooting

\section{Introduction}

One of the most cultivated fruit species is grape (Vitis vinifera L.) which is originated from temperate zones of Asia minor in the regions between the south of the Black and the Capsian seas and subsequently spreading towards tropical areas to the west and to the east (Vaddar, 2007; Galavi et al., 2013).

Phylloxera, an insect from North America, was detected in France in 1868. The spreading of Phylloxera in most of the French and European vineyards was extremely rapid. Vinifera is susceptible to the attack of phylloxera. Phylloxera attacked vineyards worldwide from the European grapevine cultivars and spreaded from vine to vine. It caused great damage all over the world. Grape plants died rapidly and in huge numbers after the roots of vinifera grapevines were attacked by phylloxera. While the phylloxera damages the roots of European vine species, V.vinifera, it cannot harm the roots of the American vine species. Phylloxera resistant rootstocks play an important part in viticulture. Grape rootstocks have been bred to provide resistance to phylloxera (Daktulosphaira vitifoliae Fitch). This situation makes the use of American vine rootstock in the production of suspended seedlings inevitably (Carew et al., 2004). Today, vinegrowers have to graft V.vinifera cultivars onto resistant rootstocks such as North American species (Baydar and Ece, 2005; Lowe and Walker, 2006; Sabir, 2011; Teker et al., 2014).

Grape is one of the most important horticulture crops of Turkey. Traditionally, grapevines have grown on their own roots, this is still a common practice in Turkey, but establishing vineyard with phylloxera resistant rootstocks is necessary for modern Turkish viticulture. In recent years, vineyards have established the usage of rootstock. Most vinegrower prefer rooted american grapevine cutting for establishing vineyard because it is 
more economical than grafted seedlings. They plant rooted american rootstock, then they make cleft grafting in the vineyard. For this reason, well rooted and full grown American rootstock cutting is very significant.

The rootstock 'Ramsey' (Vitis champini) which has great potential to be used as grape rootstock owing to its resistance to phylloxera and nematode is one of the most important rootstocks used in Turkey, especially drought climatic conditions, calcareous and high salinity soils. Ramsey cuttings are difficult to root, for this reason the root stocks cutting are dipped in 1500 to $2000 \mathrm{ppm}$ of indolebutyric acid (IBA) solution in nursery.

Plant growth-promoting rhizobacteria (PGPR) are free-living soil bacteria that can affect plant growth by the synthesis of phytohormones and vitamins, inhibiting plant ethylene synthesis, enhancing stress resistance, improving nutrient uptake and mineralising organic phosphate (Barnaval et al., 2014; Daler and Çetin, 2017). PGPR can influence the expression of root traits, such as root branching intensity, average root diameter, but mainly research has been conducted to reveal the effects of PGPR on plant growth, graft success and vegetative growth (Sabır, 2013; Karaca and Sabır, 2018). Grapevines form mutualistic symbioses with PGPR that have shown enhanced plant growth and nutrition. In the field, PGPR may be low or nonexistent (in fumigated soils), suggesting the need for PGPR inoculation of grapevine plants at the nursery. Addition of PGPR inoculum to roots could be an effective strategy for increasing nursery production (Aguin et al., 2004). Using PGPR is important in nursery. Hence, future studies will focus on enhancing nursery methods to improve successful rooting rate. PGPR can have effects on initiating easy rooting of rootstock plants like Ramsey. This study was performed in nursery, in order to identify the effects of different doses of PGPR and IBA concentrations on american rootstock scion. The effectiveness of root zone inoculation with PGPR and IBA to improve successful rooting rate on Ramsey scion were studied.

\section{Materials and Methods}

This study was carried out at Tekbağ Nursery Co. Ltd. in Manisa, Turkey, in 20172018.

\section{Plant Material}

Hardwood cuttings of Ramsey rootstocks were used as plant propagation materials in this study. Ramsey has high vigour, nematode (Meloidogyne) resistance and salt tolerance, moderate to high phylloxera resistance, moderate tolerance of drought and lime, but can suffer from zinc deficiencies in high $\mathrm{pH}$ soils. However, it has the lowest success of rooting and affinity ratio when it is compared to other rootstocks (Lowe and Walker, 2006).

The cuttings were collected from dormant vines. All cuttings were taken from the same parts (between $3^{\text {rd }}-10^{\text {th }}$ nodium) of mother vines. They were placed in cold storage at $1-$ $5^{\circ} \mathrm{C}$ and high relative humidity until the experiment. The plant materials were cut into 40 $\mathrm{cm}$ sections with an average of four nodes each. A total of 1800 cuttings were collected for two years.

\section{Plant Growth-Promoting Rhizobacteria (PGPR) and IBA Applications}

Plant Growth-Promoting Rhizobacteria (PGPR) and indolebutyric acid (IBA) have been applied to increase development of cuttings.

Plant Growth-Promoting Rhizobacteria: PGPR used in the research is EM•A that was obtained from the "EM AGRITON" company in the form of ready-to-use solution. It 
provides all the useful properties of active microorganisms technology. This is a one hundred percent organic product containing lactic acid bacteria (Lactobacillus Fermentum, L. Plantarum, L. Rhamnous, L. Delbrueckii), yeast (Saccharomyces Cerevisiae), phototrophic bacteria (Rhodopseudomonas Palustris) and Bacillus Subtilis. It has a 1.9x $10^{8}$ ${ }^{* *}$ total microorganism count $\left({ }^{* *} 6.1 \times 10^{7}\right.$ aerobic, mesophilic bacteria; $1.3 \times 10^{8}$, anaerobic microarofil bacteria; $6.0 \times 10^{5}$; yeast; $<100$ mildew) and a $3.89 \mathrm{pH}$.

Indolebutyric acid: IBA is a plant hormone in the auxin family and is an ingredient in many commercial horticultural plant rooting products. Generally, IBA is used to initiate root formation in nursery.

\section{Methods}

In the experiment, IBA was applied to Ramsey cuttings with different methods at different time and doses (Alley, 1980; Kroin, 2008). EM•A was applied to cuttings with different methods at different time and doses. All applications of EM•A and IBA used in the research are given in Table 1.

After treatments, cuttings were planted in plastic pots containing uniform mixture of peat $\left(1.034 \% \mathrm{~N}, 0.94 \% \mathrm{P}_{2} \mathrm{O}_{5}, 0.64 \% \mathrm{~K}_{2} \mathrm{O}, \mathrm{pH} 5.88\right.$, Klassman $\left.{ }^{\circledR}\right)$ and inert perlite $(0-3 \mathrm{~mm}$ in diameter) in equal volume. Before planting, $5 \mathrm{~cm}$ top parts of the cuttings were covered with red colored paraffin which melts at $70^{\circ} \mathrm{C}$. They were placed in a greenhouse at $28^{\circ} \mathrm{C}$ and $60 \%$ relative humidity for 6 weeks after preparation.

Table 1. Introduction of applications

\begin{tabular}{|c|c|}
\hline EMA1 & $\begin{array}{l}10 \mathrm{~cm} \text { bottom parts of cuttings were immersed in } \mathrm{EM} \bullet \mathrm{A} \text { solution at a dose of } 100 \mathrm{mg} / \mathrm{L} \\
\text { for } 1 \text { hour and then planted in pots. }\end{array}$ \\
\hline EMA6 & $\begin{array}{l}10 \mathrm{~cm} \text { bottom parts of cuttings were immersed in EM } \bullet A \text { solution at a dose of } 100 \mathrm{mg} / \mathrm{L} \\
\text { for } 6 \text { hour and then planted in pots. }\end{array}$ \\
\hline EMA24 & $\begin{array}{l}10 \mathrm{~cm} \text { bottom parts of cuttings were immersed in EM•A solution at a dose of } 100 \mathrm{mg} / \mathrm{L} \\
\text { for } 24 \text { hour and then planted in pots. }\end{array}$ \\
\hline EMA MEDIA & $\mathrm{EM} \bullet \mathrm{A}$ at a dose of $100 \mathrm{mg} / \mathrm{L}$ was injected into the rooting media shortly after planting. \\
\hline $\begin{array}{l}\text { EMA } \\
\text { CALLUS }\end{array}$ & $\begin{array}{l}\text { Callus tissue was formed at the bottom of the rootstocks in the stratification room with } \\
28^{\circ} \mathrm{C} \text { temperature and } 85 \% \text { humidity in } 21 \text { days. The callus tissue at basal ends of } \\
\text { cuttings were immersed in EM•A solution at a dose of } 200 \mathrm{mg} / \mathrm{L} \text { using quick dip } \\
\text { method ( } 4 \text { second). After, cuttings were planted in pots. }\end{array}$ \\
\hline $\begin{array}{l}\text { EMA QUICK } \\
\text { DIP }\end{array}$ & $\begin{array}{l}\text { The basal ends of cuttings were immersed in EM•A solution at a dose of } 200 \mathrm{mg} / \mathrm{L} \\
\text { using quick dip method ( } 4 \text { second) and then cuttings were planted in pots. }\end{array}$ \\
\hline IBA25 & $\begin{array}{l}10 \mathrm{~cm} \text { bottom parts of cuttings were immersed in IBA solution at a dose of } 25 \mathrm{mg} / \mathrm{L} \\
\text { for } 24 \text { hour (basal long-soak method) and then planted in pots. }\end{array}$ \\
\hline IBA2000 & $\begin{array}{l}\text { The basal ends of cuttings were immersed in IBA solution at a dose of } 2000 \mathrm{mg} / \mathrm{L} \\
\text { using quick dip method ( } 4 \text { second) and then cuttings were planted in pots. }\end{array}$ \\
\hline IBA4000 & $\begin{array}{l}\text { The basal ends of cuttings were immersed in IBA solution at a dose of } 4000 \mathrm{mg} / \mathrm{L} \\
\text { using quick dip method ( } 4 \text { second) and then cuttings were planted in pots. }\end{array}$ \\
\hline CONTROL & Cuttings are directly planted in pots without any application. \\
\hline
\end{tabular}

\section{Evaluation of Growth Parameters for Ramsey}

For the analyses of root distrubution of the cuttings to PGPR and IBA plant materials were visually evaluated 6 weeks after operation for root distrubition. The growth of the cuttings was assessed by rooting rate (\%), rooting degree (0-4), root number, root length $(\mathrm{cm})$, fresh root weight $(\mathrm{g})$, dry root weight $(\mathrm{g})$, stoma number, shoot length $(\mathrm{cm})$, shoot weight $(\mathrm{g})$, number of internodes on main shoot, lenght of lignified summer shoot $(\mathrm{cm})$, 
leaf area $\left(\mathrm{LA}, \mathrm{cm}^{2}\right)$, leaf weight $(\mathrm{gr})$, correlation between leaf area and leaf weight following the PGPR and IBA applications.

\section{Statistical Analysis}

A completely randomized simple factorial design with three replications (30 cuttings in each replication) was used in the experiment. The data were subjected to analysis of variance by SPSS (SSPS Inc. 10.0, USA, 1999) software, and differences between means were determined by Fischer's Least Significant Difference $(L S D)$ test.

\section{Results}

All data examined in the research are given in Table 2, Table 3 and Table 4 for experimental years.

Applications were determined to have a statistically significant effect $(\mathrm{P}=0.001)$ on the rooting rate (\%) for Ramsey grapevine rootstock in 2017 and 2018 experimental years. The EMA1 and EMA6 applications in the first experimental year were included in the same statistical group for rooting rate (\%) 56.7 (a), 50.0 (ab), respectively (Table 2, Fig.1), on the other hand in the second year EMA1 and EMA6 applications were in the same statistics group, 56.7 (a), 56.7 (a), respectively (Table 3, Fig. 1).

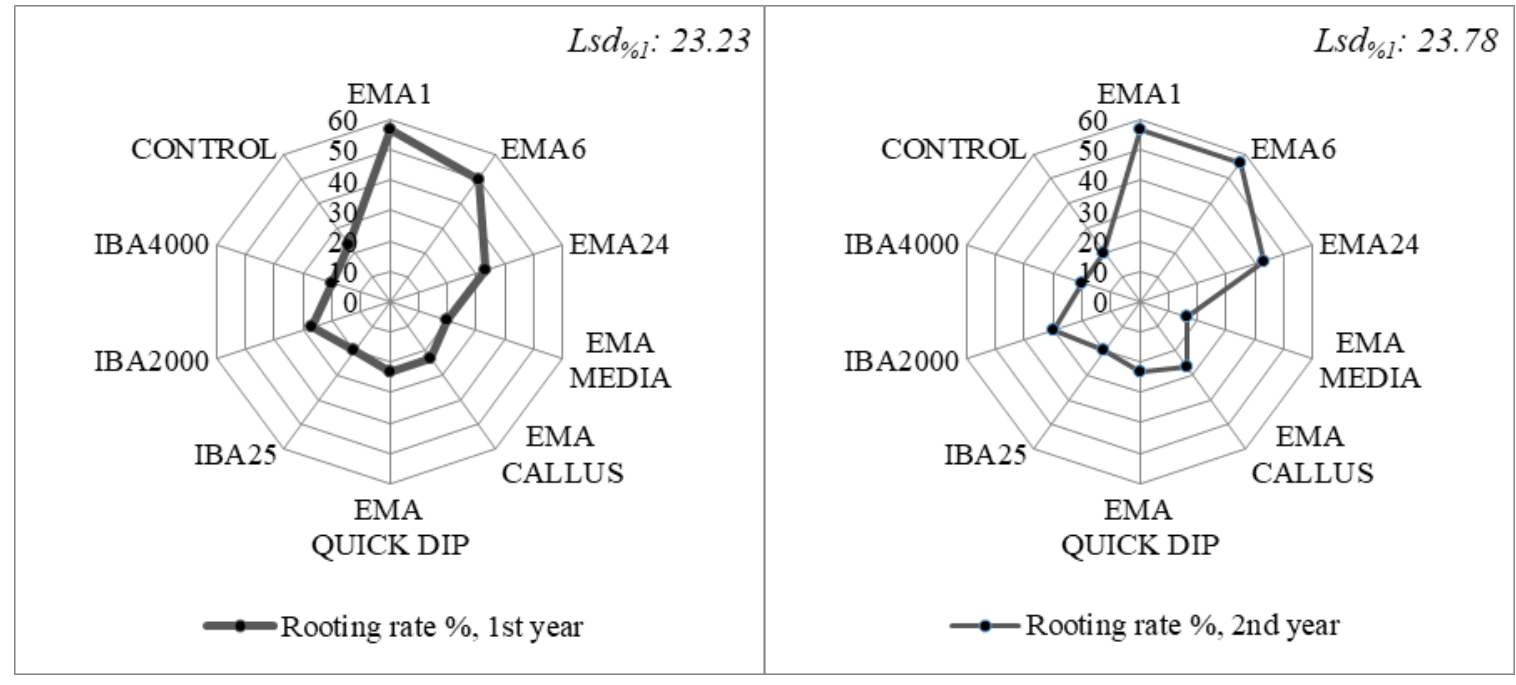

Figure 1. Rooting rate (\%) for 2017 and 2018 application years

When we extend the statistical evaluation by considering the year as a factor, EMA1 and EMA6 applications were included in the same statistical group for rooting rate (\%) performances in both experimental year, 56.7 (a), 53.3 (a), respectively (Table 4).

The fresh root weight $(\mathrm{g})$ was measured with a $0.0001 \mathrm{~g}$ sensitive analytical balance and indicated in grams $(\mathrm{g})$. Applications were determined to have a statistically significant effect on fresh root weight $(\mathrm{g})$ in the first year, the best results were determined with EMA6 (10.6 a) and EMA1 (9.4 ab) (Table 2, Fig. 2). On the other hand there was no difference between applications in the second year (Table 3, Fig. 2). When both application years were evaluated together, EMA1 (9.8 a) and EMA6 (9.5 ab) were determined to be in the same statistical group like in the first year (Table 4). 


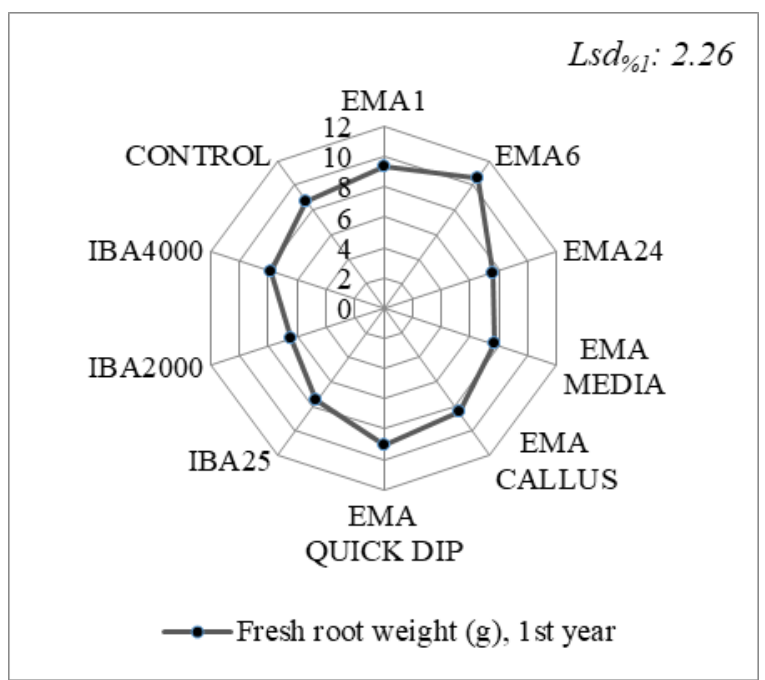

Figure 2. Fresh root weights (g) for 2017 application year

While the best result with dry root weight was determined with EMA6 (6.7 a) and CONTROL (6.2 a) in the first year (Table 2), in the second year, CONTROL (6.2 a), EMA1 (5.9 ab) and EMA24 (5.9 ab) applications were obtained in the same statistical group (Table 3, Fig. 3). In both year, best results were obtained form EMA1 (9.8 a) and EMA6 (9.5 ab) (Table 4).

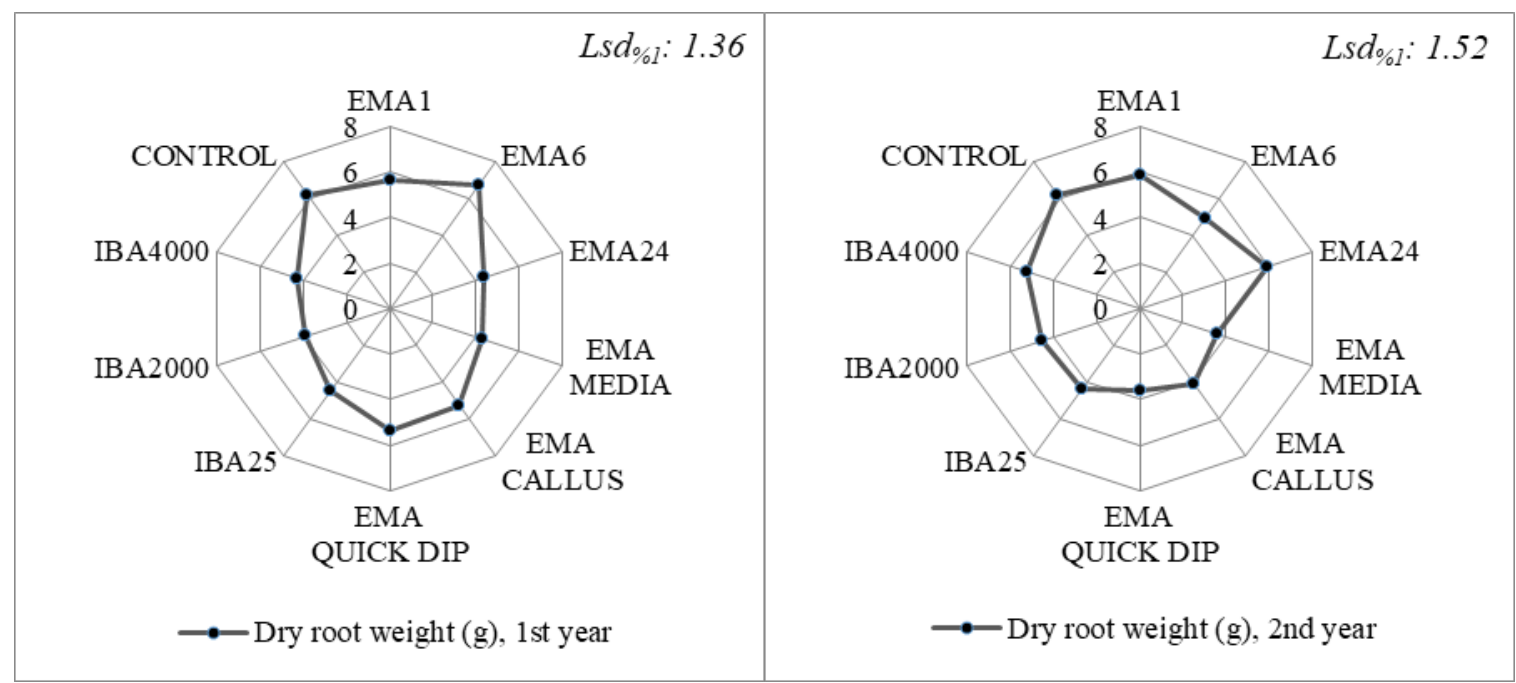

Figure 3. Dry root weights (g) for 2017 and 2018 application years

Stoma number was found 38.3 (a) with EMA CALLUS for the first year (Table 2). In the second year, EMA1 and EMA QUICK DIP application were in the same statistical group, 30.7 (a) and 29.7 (a), respectively (Table 3, Fig. 4).

When cuttings analyzed for shoot length $(\mathrm{cm})$, number of internodes on main shoot, lenght of lignified summer shoot $(\mathrm{cm})$, shoot weight $(\mathrm{g})$ and root number, there were not significantly influenced by PGPR and IBA treatment for 2017 and 2018 treatment years (Table 2, Table 3). When we extended the statistical evaluation by considering the year as a factor, same results were obtained for all these values (Table 4). 


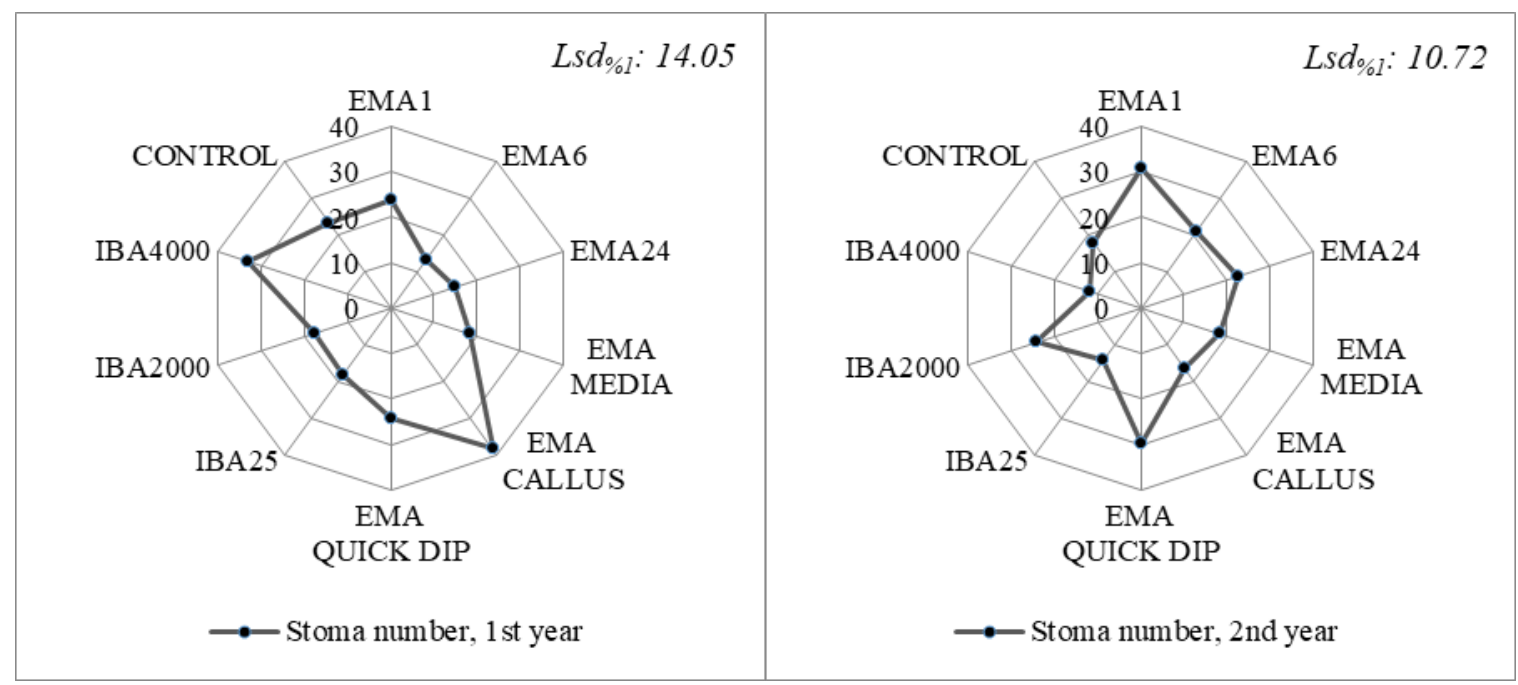

Figure 4. Stoma number for 2017 and 2018 application years

There was no significant difference in the success of root lenght $(\mathrm{cm})$ PGPR and IBA applications in the first year of application (Table 2). The highest positive effect of PGPR application on root lenght $(\mathrm{cm})$ of Ramsey was observed in the second year in EMA MEDIA (41.2 a) and EMA1 (35.0 ab), they were in the same statistical group (Table 3, Fig. 5).

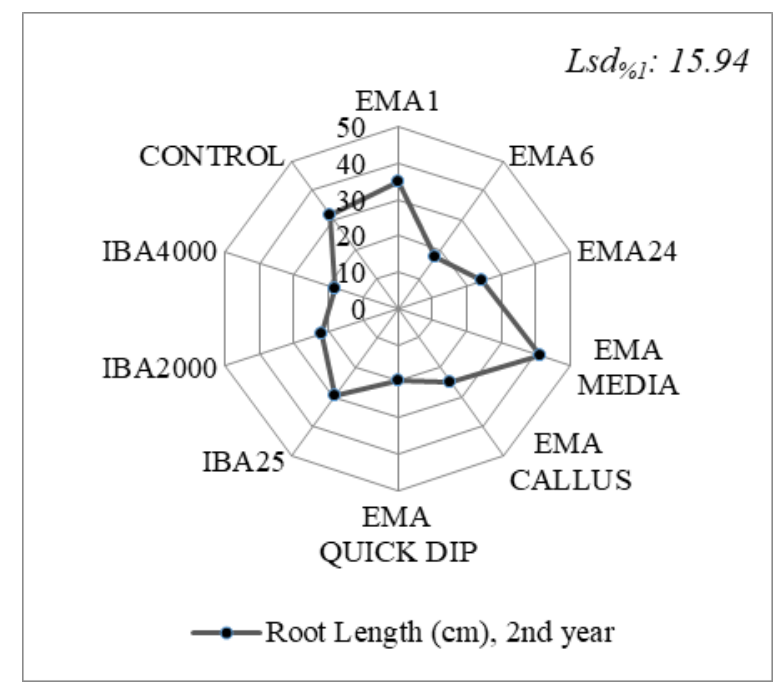

Figure 5. Root length (cm) for 2018 application year

The effect of EMA MEDIA (37.2 a), IBA25 (37.6 a) and EMA1 (34.1 ab) for root lenght $(\mathrm{cm})$ were observed in the same statistical class in both year (Table 4).

The root number was not affected by PGPR and IBA applications. No statistical difference was found (Table 2, Table 3, Table 4 ).

When it comes to the effect of PGPR and IBA application on Ramsey rooting degree (04), it is observed that PGPR inoculated plants have the highest level of rooting degree at EMA MEDIA (3.7 a), IBA4000 (3.7 a) and EMA1 (3.3 ab) and these were in the same statistics group for the first year (Table 2). There was no statistical difference between the second year applications, but the EMA1 had the highest 3.7 value (Table 3, Fig. 6). 


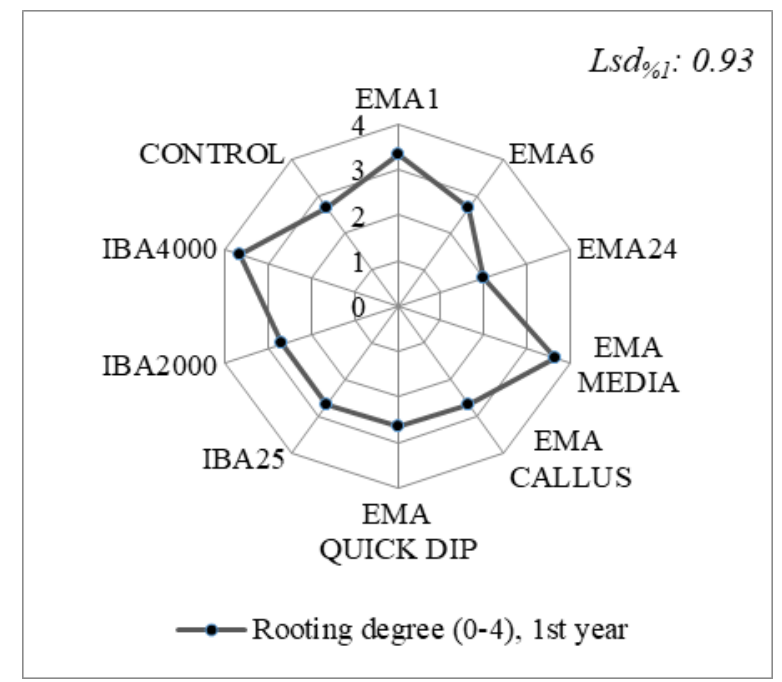

Figure 6. Rooting degree (0-4) for 2017 application year

An overall evaluation of the data demonstrated that there were statistically important increases in the rooting rate (\%) of Ramsey by EMA1 (3.5 a) and EMA MEDIA (3.3 ab) of PGPR when the two-year data is evaluated (Table 4).

In the first year, EMA1 (53.5 a), EMA QUICK DIP (52.5 a), CONTROL (52.0 a) and EMA24 (50.9 a) gave the best results for leaf area $\left(\mathrm{cm}^{2}\right)$ (Table 2), statistics groups changed in the second year, but EMA1 (51.6 a) application gave the best result again. EMA MEDIA (51.7 a), IBA25 (50.1 a) and IBA2000 (49.9 a) were found to be of the same importance (Table 3). Eventually, the leaf area was affected positively by EMA1 (52.6 a) application in both year (Table 4).

The leaf weight (g) value was not affected by PGPR and IBA applications, no statistical difference was found between applications in year 2017 and 2018 (Table 2, Table 3). When the two experimental years were evaluated together, the leaf weight value was increased by EMA1 (1.35 a) (Table 4).

As a result of the measurement of leaf area and leaf weight (g) values, it was determined that these two criteria were directly proportional to each other. It was determined that leaf weight increased as leaf area value increased (Fig. 7).

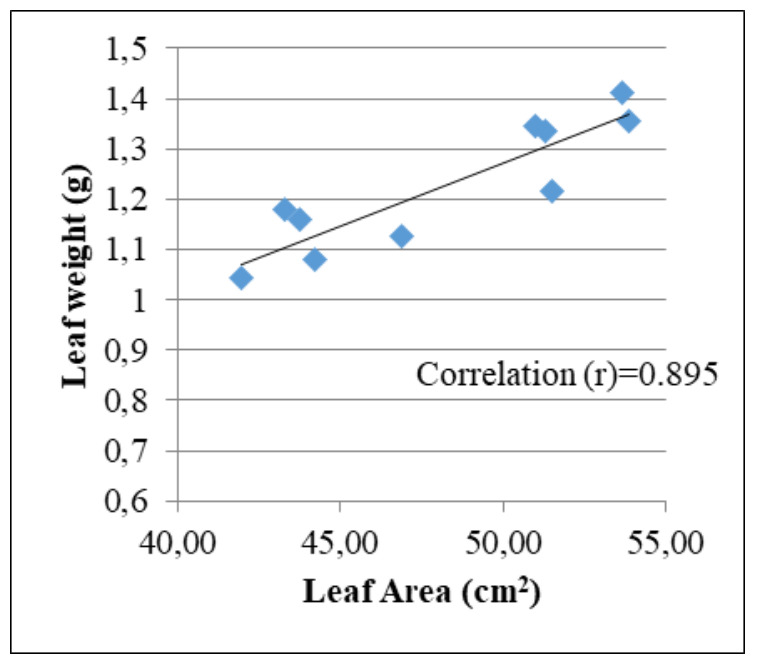

Figure 7. Correlation between leaf area and weight for both experimental years 
Table 2. First year (2017) results of PGPR and IBA applications to Ramsey rootstock cuttings.

\begin{tabular}{|c|c|c|c|c|c|c|c|c|c|c|c|}
\hline $\begin{array}{ll}\text { Criteria } & \text { Applications } \\
\end{array}$ & EMA1 & EMA6 & EMA24 & $\begin{array}{c}\text { EMA } \\
\text { MEDIA }\end{array}$ & $\begin{array}{l}\text { EMA } \\
\text { CALLUS }\end{array}$ & $\begin{array}{c}\text { EMA } \\
\text { QUICK } \\
\text { DIP }\end{array}$ & IBA25 & IBA2000 & IBA4000 & CONTROL & $L S D$ \\
\hline Rooting rate (\%) & $56.7 \mathrm{a}$ & $50.0 \mathrm{ab}$ & $33.3 \mathrm{bc}$ & $20.0 \mathrm{c}$ & $23.3 \mathrm{c}$ & $23.3 \mathrm{c}$ & $20.0 \mathrm{c}$ & $26.7 \mathrm{c}$ & $20.0 \mathrm{c}$ & $23.3 \mathrm{c}$ & $\% 1=23.23$ \\
\hline Fresh root weight (g) & $9.4 \mathrm{ab}$ & $10.6 \mathrm{a}$ & $7.6 \mathrm{bc}$ & $7.7 \mathrm{bc}$ & $8.5 \mathrm{abc}$ & $9.0 \mathrm{ab}$ & $7.6 \mathrm{bc}$ & $6.4 \mathrm{c}$ & $7.9 \mathrm{bc}$ & $8.7 \mathrm{ab}$ & $\% 1=2.26$ \\
\hline Dry root weight (g) & $5.7 \mathrm{abc}$ & $6.7 \mathrm{a}$ & 4.4 cde & $4.3 \mathrm{~d}$ & $5.2 \mathrm{bcd}$ & $5.4 \mathrm{abcd}$ & $4.5 \mathrm{cde}$ & $3.9 \mathrm{e}$ & $4.3 \mathrm{cde}$ & $6.2 a b$ & $\% 1=1.36$ \\
\hline Stoma Number & $24.0 \mathrm{bc}$ & $13.3 \mathrm{c}$ & $15.0 \mathrm{c}$ & $18.3 \mathrm{c}$ & $38.3 \mathrm{a}$ & $24.3 \mathrm{abc}$ & $18.0 \mathrm{c}$ & $17.7 \mathrm{c}$ & $33.0 \mathrm{ab}$ & $23.3 \mathrm{bc}$ & $\% 5=14.05$ \\
\hline Shoot Length (cm) & 58.8 & 57.6 & 73.2 & 66.0 & 66.8 & 56.1 & 70.3 & 54.0 & 76.0 & 48.0 & $n s$ \\
\hline Number of internodes on main shoot & 16.3 & 14.3 & 18.3 & 16.2 & 12.4 & 15.0 & 19.6 & 14.0 & 19.1 & 14.8 & $n s$ \\
\hline Length of lignified summer shoot $(\mathbf{c m})$ & 4.9 & 4.0 & 2.8 & 4.0 & 4.1 & 1.6 & 9.0 & 3.3 & 5.8 & 2.1 & $n s$ \\
\hline Shoot weight (g) & 14.3 & 13.4 & 16.8 & 21.1 & 17.9 & 8.6 & 20.7 & 16.0 & 17.3 & 17.0 & $n s$ \\
\hline Root length $(\mathrm{cm})$ & 33.3 & 29.3 & 22.7 & 33.1 & 25.4 & 17.8 & 45.6 & 20.7 & 26.8 & 34.7 & $n s$ \\
\hline Root number & 6.0 & 6.0 & 5.3 & 7.7 & 3.7 & 7.0 & 7.3 & 6.0 & 8.3 & 5.7 & $n s$ \\
\hline Rooting degree $(0-4)$ & $3.3 \mathrm{ab}$ & $2.7 \mathrm{bc}$ & $2.0 \mathrm{c}$ & $3.7 \mathrm{a}$ & $2.7 \mathrm{bc}$ & $2.7 \mathrm{bc}$ & $2.7 \mathrm{bc}$ & $2.7 \mathrm{bc}$ & $3.7 \mathrm{a}$ & $2.7 \mathrm{bc}$ & $\% 5=0.93$ \\
\hline Leaf area $\left(\mathrm{cm}^{2}\right)$ & $53.5 \mathrm{a}$ & $50.7 \mathrm{ab}$ & $50.9 \mathrm{a}$ & $46.5 \mathrm{abc}$ & $40.8 \mathrm{c}$ & $52.5 \mathrm{a}$ & $42.8 \mathrm{c}$ & $42.0 \mathrm{c}$ & $43.1 \mathrm{bc}$ & $52.0 \mathrm{a}$ & $\% 1=1.36$ \\
\hline Leaf weight (g) & 1.38 & 1.27 & 1.16 & 1.26 & 1.07 & 1.17 & 1.17 & 1.41 & 1.22 & 1.25 & $n s$ \\
\hline
\end{tabular}

1.38

Columns means followed by the same letter are not significantly different at 0.01 probability

Table 3. Second year (2018) results of PGPR and IBA applications to Ramsey rootstock cuttings.

\begin{tabular}{|c|c|c|c|c|c|c|c|c|c|c|c|}
\hline Criteria Applications & EMA1 & EMA6 & EMA24 & $\begin{array}{c}\text { EMA } \\
\text { MEDIA }\end{array}$ & $\begin{array}{c}\text { EMA } \\
\text { CALLUS }\end{array}$ & $\begin{array}{l}\text { EMA } \\
\text { QUICK } \\
\text { DIP }\end{array}$ & IBA25 & IBA2000 & IBA4000 & CONTROL & $L S D$ \\
\hline Rooting rate (\%) & $56.7 \mathrm{a}$ & $56.7 \mathrm{a}$ & $43.3 \mathrm{ab}$ & $16.7 \mathrm{c}$ & $26.7 \mathrm{bc}$ & $23.3 \mathrm{bc}$ & $20.0 \mathrm{c}$ & $30.0 \mathrm{bc}$ & $20.0 \mathrm{c}$ & $20.0 \mathrm{c}$ & $\% 1=20.78$ \\
\hline Fresh root weight (g) & 10.2 & 8.4 & 9.3 & 6.7 & 7.5 & 6.7 & 7.6 & 7.8 & 8.5 & 8.2 & $n s$ \\
\hline Dry root weight (g) & $5.9 \mathrm{ab}$ & $4.9 \mathrm{abcd}$ & $5.9 \mathrm{ab}$ & $3.6 \mathrm{~d}$ & $4.1 \mathrm{~cd}$ & $3.6 \mathrm{~d}$ & $4.4 \mathrm{~cd}$ & $4.6 \mathrm{bcd}$ & $5.2 \mathrm{abc}$ & $6.2 \mathrm{a}$ & $\% 1=1.52$ \\
\hline Stoma Number & $30.7 \mathrm{a}$ & $20.7 \mathrm{abc}$ & $22.7 \mathrm{ab}$ & $18.3 \mathrm{bc}$ & $16.3 \mathrm{bc}$ & $29.7 \mathrm{a}$ & $14.3 \mathrm{bc}$ & $24.3 \mathrm{ab}$ & $11.7 \mathrm{c}$ & $17.7 \mathrm{bc}$ & $\% 5=10.72$ \\
\hline Shoot Length $(\mathrm{cm})$ & 54.1 & 62.4 & 68.6 & 57.7 & 56.4 & 61.2 & 59.7 & 60.1 & 55.9 & 70.3 & $n s$ \\
\hline Number of internodes on main shoot & 16.5 & 14.6 & 16.6 & 15.5 & 14.7 & 16.6 & 16.9 & 15.5 & 14.7 & 17.8 & $n s$ \\
\hline Length of lignified summer shoot $(\mathrm{cm})$ & 1.8 & 3.3 & 0.8 & 7.3 & 2.0 & 6.7 & 4.0 & 0.0 & 1.0 & 4.4 & $n s$ \\
\hline Shoot weight (g) & 11.4 & 16.9 & 16.5 & 16.7 & 9.5 & 13.2 & 13.2 & 9.6 & 25.2 & 16.2 & $n s$ \\
\hline Root length $(\mathbf{c m})$ & $35.0 \mathrm{ab}$ & $17.3 \mathrm{c}$ & $24.5 \mathrm{bc}$ & $41.2 \mathrm{a}$ & $25.0 \mathrm{bc}$ & $19.8 \mathrm{bc}$ & $29.7 \mathrm{abc}$ & $22.1 \mathrm{bc}$ & $18.0 \mathrm{c}$ & $31.6 \mathrm{abc}$ & $\% 1=15.94$ \\
\hline Root number & 7.3 & 6.3 & 8.3 & 8.7 & 6.3 & 6.0 & 8.3 & 5.3 & 5.0 & 5.7 & $n s$ \\
\hline Rooting degree (0-4) & 3.7 & 2.3 & 2.3 & 3.0 & 3.0 & 2.0 & 3.3 & 3.0 & 2.3 & 2.7 & $n s$ \\
\hline Leaf area $\left(\mathrm{cm}^{2}\right)$ & $51.6 \mathrm{a}$ & $46.5 \mathrm{ab}$ & $42.1 \mathrm{~b}$ & $51.7 \mathrm{a}$ & $46.0 \mathrm{ab}$ & $44.2 \mathrm{ab}$ & $50.1 \mathrm{a}$ & $49.9 \mathrm{a}$ & $46.5 \mathrm{ab}$ & $46.2 \mathrm{ab}$ & $\% 1=7.63$ \\
\hline Leaf weight $(\mathrm{g})$ & 1.32 & 1.18 & 1.14 & 1.31 & 1.19 & 1.21 & 1.29 & 1.23 & 1.12 & 1.37 & $n s$ \\
\hline
\end{tabular}

Columns means followed by the same letter are not significantly different at 0.01 probability 
Table 4. Both experimental years (2017-2018) results of PGPR and IBA applications to Ramsey rootstock cuttings.

\begin{tabular}{|c|c|c|c|c|c|c|c|c|c|c|c|}
\hline Criteria & EMA1 & EMA6 & EMA24 & $\begin{array}{c}\text { EMA } \\
\text { MEDIA }\end{array}$ & $\begin{array}{c}\text { EMA } \\
\text { CALLUS }\end{array}$ & $\begin{array}{c}\text { EMA } \\
\text { QUICK } \\
\text { DIP }\end{array}$ & IBA25 & IBA2000 & IBA4000 & CONTROL & $L S D$ \\
\hline $\begin{array}{l}\text { Rooting rate } \\
(\%)\end{array}$ & $56.7 \mathrm{a}$ & $53.3 \mathrm{a}$ & $38.3 \mathrm{~b}$ & $18.3 \mathrm{c}$ & $25.0 \mathrm{bc}$ & $23.3 \mathrm{c}$ & $20.0 \mathrm{c}$ & $28.3 \mathrm{bc}$ & $20.0 \mathrm{c}$ & $21.7 \mathrm{c}$ & $\%=13.63$ \\
\hline $\begin{array}{l}\text { Fresh root } \\
\text { weight (g) }\end{array}$ & $9.8 \mathrm{a}$ & $9.5 \mathrm{ab}$ & $8.4 \mathrm{abc}$ & $7.2 \mathrm{c}$ & $8.0 \mathrm{abc}$ & $7.9 \mathrm{abc}$ & $7.6 \mathrm{c}$ & $7.1 \mathrm{c}$ & $8.2 \mathrm{abc}$ & $8.4 \mathrm{abc}$ & $l=1.97$ \\
\hline $\begin{array}{l}\text { Dry root weight } \\
\text { (g) }\end{array}$ & $5.8 \mathrm{ab}$ & $5.8 \mathrm{ab}$ & $5.1 \mathrm{abc}$ & $3.9 \mathrm{c}$ & $4.65 \mathrm{bc}$ & $4.5 \mathrm{c}$ & $4.4 \mathrm{c}$ & $4.2 \mathrm{c}$ & $4.7 \mathrm{bc}$ & $6.2 \mathrm{a}$ & $\% 1=1.25$ \\
\hline Stoma Number & 27.3 & 17.0 & 18.8 & 18.3 & 27.3 & 27.0 & 16.2 & 21.0 & 22.3 & 20.5 & $n s$ \\
\hline $\begin{array}{l}\text { Shoot Length } \\
\text { (cm) }\end{array}$ & 56.4 & 60.0 & 70.9 & 61.8 & 61.6 & 58.6 & 65.0 & 57.0 & 65.9 & 59.1 & $n s$ \\
\hline $\begin{array}{l}\text { Number of } \\
\text { internodes on } \\
\text { main shoot }\end{array}$ & 16.4 & 14.4 & 17.4 & 15.8 & 13.5 & 15.8 & 18.3 & 14.7 & 16.9 & 16.3 & $n s$ \\
\hline $\begin{array}{l}\text { Length of } \\
\text { lignified } \\
\text { summer shoot } \\
\text { (cm) }\end{array}$ & 3.36 & 3.6 & 1.8 & 5.3 & 3.2 & 4.6 & 6.5 & 3.3 & 3.8 & 3.3 & $n s$ \\
\hline Shoot weight (g) & 12.9 & 15.1 & 16.7 & 18.9 & 13.7 & 10.9 & 17.0 & 12.8 & 21 & 16. & $n s$ \\
\hline $\begin{array}{l}\text { Root length } \\
\text { (cm) }\end{array}$ & $34.1 \mathrm{ab}$ & $23.3 \mathrm{bc}$ & $23.6 \mathrm{bc}$ & $37.2 \mathrm{a}$ & $25.2 \mathrm{abc}$ & $18.8 \mathrm{c}$ & $37.6 \mathrm{a}$ & $21.4 \mathrm{bc}$ & $22.4 \mathrm{bc}$ & $33.1 \mathrm{ab}$ & $\% 5=13.42$ \\
\hline Root number & 6.7 & 6.2 & 6.8 & 8.2 & 5.0 & 6.5 & 7.8 & 5.7 & 6.7 & 5.7 & $n s$ \\
\hline $\begin{array}{l}\text { Rooting degree } \\
(0-4)\end{array}$ & $3.5 \mathrm{a}$ & $2.5 \mathrm{~cd}$ & $2.2 \mathrm{~d}$ & $3.3 \mathrm{ab}$ & $2.8 \mathrm{abc}$ & $2.3 \mathrm{~cd}$ & $3.0 \mathrm{ab}$ & $2.8 \mathrm{ab}$ & $3.0 \mathrm{abc}$ & $2.7 \mathrm{~b}$ & $\% 5=0.80$ \\
\hline Leaf area $\left(\mathrm{cm}^{2}\right)$ & $\begin{array}{l}52.6 \mathrm{a} \\
135 \mathrm{a}\end{array}$ & $\begin{array}{l}48.6 \mathrm{abc} \\
1.22 \mathrm{abcd}\end{array}$ & $\begin{array}{l}46.5 \mathrm{bc} \\
1.15 \mathrm{~cd}\end{array}$ & $\begin{array}{l}49.1 \mathrm{ab} \\
1.29 \mathrm{abc}\end{array}$ & $\begin{array}{l}43.4 \mathrm{c} \\
1.13 \mathrm{~d}\end{array}$ & $\begin{array}{l}48.3 \mathrm{abc} \\
1.19 \mathrm{bcd}\end{array}$ & $\begin{array}{c}46.5 \mathrm{bc} \\
1.23 \mathrm{abcd}\end{array}$ & $\begin{array}{l}45.9 \mathrm{bc} \\
1.32 \mathrm{ab}\end{array}$ & $\begin{array}{l}44.8 \mathrm{bc} \\
1.17 \mathrm{bcd}\end{array}$ & $\begin{array}{l}49.1 \mathrm{ab} \\
1.31 \mathrm{ab}\end{array}$ & $\begin{array}{l}\% 1=5.39 \\
\%_{5}=0.15\end{array}$ \\
\hline
\end{tabular}

Columns means followed by the same letter are not significantly different at 0.01 probability 


\section{Discussion}

Intensive nursery practice in viticulture still relies on the use of plant hormones like auxin to provide dense root formation and healty root development. It is very well known that IBA can stimulate root formation of cuttings. The essential role of IBA has been documented on induction of rooting and root formation (Galavi et al., 2013). Hartmann et al. (1997) reported that IBA application have impressive results in rooting the semihardwood cuttings in apple, plum and olive. Therefore, use of IBA has been recommended for rooting of grapevine rootstocks cuttings on the basis of the evidence reported in the literature by a great number of researchers (Yağc1, 2015). On the other hand, excessive use of hormone causes problems not only in terms of financal cost but also in terms of the cost to the environment. Therefore, the development and application of sustainable agricultural techniques is vital to decrease environmental pollution (Sabir, 2013). Many research on viticulture using PGPR resulted in enhanced plant growth, disease resistance, improved nutrient fixation or solution and graft success. Using different hardwood grafting type and varieties, Köse et al. (2003) and Köse et al. (2005) demonstrated that there were statistically important increase in the survival of grafts in relation with PGPR applications. In the current studies, PGPR inoculation alone or in combination markedly helped the young plants to survive and success in rooting.

This report provides the first data to demonstrate that PGPR applications can increase rooting rate (\%) and full rooting characteristics in hardwood cuttings of Ramsey grapevine rootstocks. In order to determine rooting criteria of hardwood cuttings applied in the seedling production process different concentration and dipping times were tested with PGPR together with IBA applications. In contrast to the results at IBA and control, applications with PGPR increased rooting rate $(\%)$, rooting degree $(0-4)$, root length $(\mathrm{cm})$, fresh and dry root weight $(\mathrm{g})$. All of these characteristics for cuttings are of the same importance in nursery practice.

PGPR and IBA applications did not have a specific influence on the root number at the base of Ramsey hardwood cuttings. However, the PGPR and IBA applications manifested their specific characteristics and showed significant variation in the number of roots, in the increasing variation of IBA4000 (8.3), EMA MEDIA (7.7), IBA25 (7.3) in the first year, and of IBA25 (8.3), EMA24 (8.3) and EMA1 (7.3) in the second year. Root number similarly responded to the change in both year in EMA MEDIA (8.2), IBA25 (7.8), EMA24 (6.8) and EMA1 (6.7).

Application of treatments, resulted in rooting rate (\%) with EMA1 and EMA6 to be 56.7 a, 53.3 a, respectively (Table 4). Interesting thing is, IBA4000 applications have reduced rooting rate $(20.0 \mathrm{c})$ in our researche. It is very well known that the hormones can stimulate root formation of cutting (Köse et al., 2003). Furthermore, Yağc1, (2015) reported the effects of IBA doses $(1000,2000,4000 \mathrm{mg} / \mathrm{L})$ on grafted sapling (different grafting combinations; Hamburg Misketi, Tekirdağ Çekirdeksizi, Italia and Trakya İlkeren cuttings/Ramsey rootstock). According to the researcher, the effect of IBA applications on rooting rate (\%) was statistically significant. On the other hand, $4000 \mathrm{mg} / \mathrm{L}$ of IBA application adversely affected rooting rate (\%), the best effect of different levels of IBA on rooting rate $(\%)$ was obtained at $2000 \mathrm{mg} / \mathrm{L}$ IBA. Some studies have reported that higher concentrations of IBA can adversely affect the rooting of cuttings (Cerveny and Gibson, 2005; Galavi et al., 2013). These results support our research. As for rooting rate (\%) around hardwood cuttings of Ramsey rootstocks, had also remarkably positive influences with the highest degrees being promoted by EMA1 and EMA6 for both experimental years (Table 4). 
Even if the values of fresh root weight $(\mathrm{g})$ were in positive order with EMA1 (9.8 a), EMA6 (9.5 ab), dry root weight (g) have reduced in CONTROL (6.2 a), EMA1 (5.8 ab) and EMA6 (5.8 ab) applications (Table 4).

As reported in some studies, IBA2000 and IBA4000 applications have reduced fresh and dry root weight $(\mathrm{g})$. These results support our research. Researchers believe that high concentrations of IBA can cause damage to the cutting base (Kelen and Demirtaş, 2001; Galavi et al., 2013; Yağc1, 2015).

Correlation analyses were carried out on the parameters indicating leaf area $\left(\mathrm{cm}^{2}\right)$ and leaf weight $(\mathrm{g})$. It was determined that leaf weight increased as leaf area value increased (Fig. 7).

When the effect of PGPR and IBA application of Ramsey hardwood cuttings is examined stoma number of the cuttings was affected by EMA CALLUS (38.3 a) in the first year (Table 2). It is observed that the inoculated plants have the highest amount of stoma number with EMA1 (30.7 a) in the second year. EMA1 and EMA QUICK DIP application were in the same statistical group, 30.7 a and 29.7 a, respectively (Table 3).

On the other hand, an overall evaluation of the data demonstrated that there were statistically important increases in the rooting rate (\%) and rooting degree (0-4) of Ramsey by EMA1 application. It is important to determine whether there is a positive relationship between these characteristics.

Comparing root lenght $(\mathrm{cm})$ among the experimental groups for the two years showed a significantly $(\mathrm{P}<0.05)$ positive effect in IBA25 (37.6 a), EMA MEDIA (37.2 a) EMA1 (34.1 ab) (Table 4).

In Table 4, where the values obtained in terms of rooting degree, it is seen that plants formed root development level on a scala of 0-4 when they are inoculated with EMA1 and EMA MEDIA. There were found statistical differencies for root development level on a scala of 0-4 with EMA1 (3.5 a) and EMA MEDIA (3.3 ab), these were in the same statistical class. Köse et al., (2003) reported that positive effects of bacterial applications on rooting of rootstock having low rooting rate may be explained by auxin and/or auxin like plant growth promoting substance production of bacterial strains. They found that the bacterial combination decreased the rooting rate and rooting degree.

\section{Conclusion}

In conclusion, Ramsey is resistant to phylloxera and salt tolerance but its use is very limited due to the difficulties in rooting ability of the cuttings. Some treatments including plant growth regulators, especially IBA and other chemical substances have been applied on the cuttings for increasing the rooting percentage. The aim of this study was to investigate the effects of the PGPR, it was used with different application time on the rooting of Ramsey rootstock, having different features (with callus and without callus). These applications were compared with the most common IBA treatment and control group plants. Our results suggest that PGPR applications may have a great potential to stimulate the rooting of hardwood cuttings of grapevine rootstocks, with low rooting capability. In our study, it seems that PGPR application has a positive effect on rooting rate $(\%)$, fresh and dry root weight $(\mathrm{g})$, root length $(\mathrm{cm})$, rooting degree $(0-4)$ and leaf area (LA, $\mathrm{cm}^{2}$ ) of rootstocks with EMA1 and EMA6 applications. The EMA1 and EMA6 applications may be of benefit for Ramsey rootstocks, particularly for organic farming.

Acknowledgements. The author would like to thank EM AGRITON Co. Ltd. for their help in obtaining PGPR sources and Tekbağ Nursery Co. Ltd. in Turkey for plants materials. 


\section{REFERENCES}

[1] Aguin, O., Mansilla, J. P., Vilarino, A., Sainz, M. J. (2004): Effects of mycorrhizal inoculation on root morphology and nursery production of three grapevine rootstocks. - Am J Enol Vitic 55: 108-111.

[2] Alley, J. C. (1980): Propagation of grapevines. - California Agriculture: 29-30.

[3] [3] Barnawal, D., Bharti, N., Maji, D., Chanotiya, C. S. (2014): ACC deaminase-containing Arthrobacter protophormiae induces $\mathrm{NaCl}$ stres tolerance through reduced ACC oxidase activity and ethylene production resulting in improved nodulation and mycorrhization in Pisum sativum. - Journal of Plant Physiology 171: 884-894.

[4] Baydar, N. G., Ece, E. (2005): Comparison of different varieties/root combinations in vaccination of grapevine cultivation in Isparta conditions. - Süleyman Demirel University. Journal of the Institute of Science and Technology: 9-5. (Turkish).

[5] Carew, M. E., Goodisman, M. A., Hoffmann, A. A. (2004): Species status andpopulation genetic structure of grapevine eriophyoid mites. - Entomologia Experimentalis et Applicata 111: 87-96.

[6] Cerveny, C., Gibson, J. (2005): Rooting hormones. - Grower 101. Crop Cultivation: 36-44. Available: www.gpnmag.com/lm.cfm/gp080503.

[7] Daler, S., Çetin, E. M. (2017): Determination of the effects of plant growth-promoting Rhizobacteria applications on Kober 5 BB american grapevine rootstock in lead stress. Journal of Biology, Agriculture and Healthcare 7(12): 50-55. ISSN 2225-093X (Online).

[8] Galavi, M., Karimian, M. A., Mousavi, S. R. (2013): Effects of different auxin (IBA) concentrations and planting-beds on rooting grape cuttings (Vitis vinifera). - Annual Review $\&$ in Biology 3(4): 517-523.

[9] Hartmann, H. T., Kester, D. E., Davies, F. T., Geneve, R. L. (1997): Plant Propagation: Principles and Practices. - Prentice-Hall, Inc., Englewood Cliffs, New Jersey. Sixth edition.

[10] Karaca, U., Sabır, A. (2018): Sustainable mitigation of alkaline stress in grapevine rootstocks (Vitis spp.) by plant growth-promoting rhizobacteria. - Erwerbs-Obstbau 60: 211-220.

[11] Kelen, M., Demirtaş, I. (2001): The effects of IBA doses with different rooting mediums on the rooting rates and root qualities of $5 \mathrm{BB}$ and $420 \mathrm{~A}$ American grapevine rootstocks. Journal of Agricultural Sciences 7(1): 142-146. (Turkish).

[12] Köse, C., Güleryüz, M., Şahin, F., Demirtaş, I. (2003): Effects of some plant growth promoting rhizobacteria (PGPR) on rooting of grapevine rootstocks - Acta Agrobotanica 56: 47-52.

[13] Köse, C., Güleryüz, M., Şahin, F., Demirtaş, I. (2005): Effects of some plant growth promoting rhizobacteria (PGPR) on graft union of grapevine. - Journal of Sustainable Agriculture 26: 139-147.

[14] Kroin, J. (2008): Propagate plants from cuttings dry-dip rooting powders and water-based rooting solutions. - Combined Proceedings International Plant Propagators Society 58: 360372.

[15] Lowe, K. M., Walker, M. A. (2006): Genetic linkage map of the interspecific grape rootstock cross Ramsey (Vitis Champinii) X Riparia Gloire (Vitis Riparia). - Theor. Appl. Genet. 112: 1582-1592.

[16] Sabir, A. (2011): Comparison of green grafting techniques for success and vegetative development of grafted grape cultivars (Vitis Spp.). - Int. J. Agric. Biol. 13: 628-630.

[17] Sabır, A. (2013): Improvement of grafting efficiency in hard grafting grape Berlandieri hybrid rootstocks by plant growth-promoting rhizobacteria (PGPR). - Scientia Horticulturae 164: 24-29.

[18] Teker, T., Ulaş S., Dolgun, O. (2014): Effects of scion-rootstock combinations on ratio and quality of the potted vine grafts. - Turkish Journal of Agricultural and Natural Sciences 2: 1898-1904.

[19] Vaddar, UB. (2007): Studies on grape rhizosphere microorganisms. - Master Thesis. Department of Agricultural Microbiology College of Agriculture, Dharwad University of Agricultural Sciences, Dharwad - 580005. 
[20] Yağc1, A. (2015): Effects of IBA applications on final take ratio and sapling quality of different grape variety and rootstock combinations in grafted vine sapling production. $-8^{\text {th }}$ Turkey Viticulture and Technology Symposium: 137-145. Konya. ISSN:1309-0550. (Turkish). 